\title{
Peran Wing In Ground Effect Craft (WIG) Terhadap Peningkatan Pendapatan Asli Daerah Jepara-Karimunjawa
}

\author{
Susilo Hadi Wibowo ${ }^{a *}$, Mashudi Rofiq ${ }^{b}$, Dimas Pratama Yuda ${ }^{c}$, Prapti Utami $^{\text {d }}$ \\ a,b,c,dPoliteknik Ilmu Pelayaran Semarang \\ a*Email: susilo@pip-semarang.ac.id \\ bEmail: fikmas@gmail.com \\ cEmail: dimas.kudus@gmail.com \\ dEmail: vania27201342@gmail.com
}

\begin{abstract}
ABSTRAK
Obyek wisata Kabupaten Jepara dan Kecamatan Karimunjawa dapat diandalkan baik wisata alam maupun biodata lautnya sehingga memikat wisatawan baik domestik, maupun mancanegara. Dalam tahun 2009 sampai 2019 terjadi peningkatan walaupun besarannya tidak konstans, hal ini cukup untuk menambah menaikkan anggaran pendapatan daerah setempat. Salah satu cara yang bisa mengangkat pamor di dunia pariwisata di era globalisasi dan era digital 4.0 dengan cara menambahkan sarana transportasi kapal Laut dengan model kapal penumpang bersayap, yang bisa terbang rendah di atas permukaan laut, lebih cepat dan lebih hemat dengan menampilkan Weigh In Ground Effek (WIG). Tujuan dari penelitian ini adalah untuk mendeskripsikan peningkatan Pendapatan Asli Daerah (PAD) atas obyek wisata dengan penambahan armada kapal penumpang cepat berbasis wing in grounds effect craft (WIG) pada obyek wisata Karimunjawa, Jepara. Penelitian ini menggunakan data kuantitatif dengan jenis assosiatif. Teknik pengumpulan data yang peneliti gunakan berdasarkan dokumentasi, studi perpustakaan serta hasil pengembangan peneliti terdahulu. Dari hasil penelitian dapat disimpulkan bahwa ada pengaruh signifikan antara kenaikan unsur penunjang pariwisata, jumlah sarana prasarana dan biaya promosi pariwisata terhadap peningkatan pendapatan daerah.
\end{abstract}

Kata Kunci : peningkatan PAD, wing in ground effect craft

\section{ABSTRAK}

Tourism objects in Jepara Regency and Karimunjawa District can be relied on for both natural tourism and marine biodata so that they attract tourists both domestically and internationally. From 2009 to 2019 there was an increase even though the amount was not constant, this was enough to increase the local Regional Revenue Budget. one way that can raise prestige in the world of tourism in the era of globalization and the digital era 4.0 is by adding means of sea ship transportation with the model of a winged passenger ship, which can fly low above sea level, faster and more efficiently by displaying the Weigh In Ground Effect (WIG). The purpose of this study is to describe the increase in local revenue (PAD) for tourism objects with the addition of a fleet of fast passenger boats based on wing in grounds effect craft (WIG) at tourism objects in Karimunjawa, Jepara. This research uses quantitative data with associative type. The data collection technique used by the researcher is based on documentation, library studies and the results of the development of previous researchers. From the results of the study it can be concluded that there is a significant effect of increasing tourism supporting elements, the number of infrastructure facilities and tourism promotion costs on increasing regional income.

Keywords: local revenue PAD, wing in ground effect craft 


\section{PENDAHULUAN}

Indikator penting dalam mengukur tingkat keberhasilan penerapan otonomi daerah adalah kemampuan keuangan, yang tercermin dalam Pendapatan Asli Daerah (PAD). Hal tersebut tertulis dalam UndangUndang No. 22 Tahun 1999 dan Undang-Undang No. 25 Tahun 1999 yang kemudian diadakan perubahan menjadi Undang-Undang No 32 Tahun 2004 dan Undang-Undang No 33 Tahun 2004 tentang Pemerintah Daerah dan tentang Perimbangan Keuangan antara Pemerintahan Pusat dan Pemerintah Daerah. Berdasar penelitian dari Tanjung, et al. (2021), Indonesia mempunyai sejumlah otonomi baru yang tertinggi di dunia. Ditambahkan pula bahwa otonomi keuangan merupakan prasyarat bagi keberadaan pemerintah daerah dan merupakan faktor kunci bagi pembangunan daerah yang stabil (Miceikiene, Skaurone \& Krikstolaitis, 2021).

Dalam menjalankan fungsi pemerintahan, faktor keuangan sangat penting karena semua kegiatan pemerintah mahal. Otonomi keuangan juga merupakan kategori penting yang dievaluasi dalam analisis stabilitas keuangan LG (Satola, Lukasz, Standard, dan Kozera, 2019). Dengan demikian, dapat dikatakan bahwa jika PAD tumbuh dan berimbas pada meningkatnya pendapatan kota, secara otomatis akan mampu membayar pajak dan hak otonomi. Sedangkan ciri utama untuk mewujudkan suatu daerah otonom yang mampu berotonomi adalah dengan keuangan daerah yang tidak hanya terletak pada kewenangan dan kemampuan untuk menggali, mengelola, dan menggunakan sumber-sumber keuangan saja, akan tetapi terletak pada bagaimana pemerintah daerah membiayai penyelenggaraan pemerintahan yang berimplikasi terhadap peningkatan kesejahteraan rakyatnya (Howlett \& Cashore, 2014).
Dalam hal ini, salah satu subsektor pembangunan yang memiliki multiplier effect untuk meningkatkan pendapatan masyarakat melalui perluasan kesempatan usaha dan lapangan kerja adalah pengembangan objek wisata. Industri wisata sebenarnya merupakan salah satu industri terbesar di dunia (Zolfani, Sedaghat, Maknoon \& Zavadskas, 2015). Pengembangan pariwisata berdampak pada aspek sosial, politik, dan ekonomi. Berdampak atas manfaat sosial misalnya mencakup aspek untuk menggalang persatuan bangsa dan negara. Upaya ini akan dapat menjadi sarana meningkatkan hubungan dan saling pengertian antar negara dan masyarakat internasional.

Berdampak pada sisi politik antara lain sebagai upaya pemersatu dan penengah akan ketegangan politik baik dalam negeri maupun luar negeri, hal ini diharapkan dengan adanya hubungan kerja di dunia pariwisata yang nantinya diharapkan bisa merupakan simbiosis mutualisme baik dalam negeri maupun luar negeri dan sebagai akibat sering bertemu dan saling memperhatikan pola kehidupan suatu daerah maupun negara sahabat sehingga memberikan rasa saling pengertian (Elita Dewi, 2002).

Dampak dan manfaat pada sektor ekonomi bisa menggugah minat pelaku ekonomi dengan membuka lapangan kerja baru yang berkaitan dengan wisata seperti industri transportasi, restoran/rumah makan, perhotelan (hotel, motel, pondok wisata, perkemahan dan lain-lainnya); home industry kerajinan, cindera mata (souvenir).

Terkait dengan masalah pembangunan kepariwisataan tersebut di atas, khususnya bidang transportasi laut, Kabupaten Jepara dan Kecamatan Karimunjawa memiliki objek-objek wisata yang dapat diandalkan baik objek wisata alam maupun biodata lautnya dengan keunikan tersendiri yang dapat memikat wisatawan baik lokal, domestik, maupun manca negara 
diharapkan dapat dikelola oleh pemerintah Kabupaten Jepara dan Kecamatan Karimunjawa sebagai pembangunan yang dapat memberikan manfaat multi dimensi secara sosial, politik, dan terutama sekali bermanfaat secara ekonomi bermanfaat ganda potensi objek pariwisata Kabupaten Jepara dan Karimunjawa yang memiliki daya tarik tersendiri karena mempunyai aneka ragam potensi alam dan keindahan laut yang unik dan khas sebagai aset pariwisata yang dapat dikembangkan dalam pembangunan kepariwisataan. Menurut data statistik yang peneliti temukan bahwa animo pariwisata yang berkunjung ke Karimunjawa melalui Kabupaten Jepara dari tahun ke tahun mengalami peningkatan.

Animo pariwisata memang telah muncul sebagai celah pasar yang berharga untuk tujuan wisata dalam satu dekade terakhir ini (Wen \& Wu, 2020). Menurut Puji Johantoro, Kepala Balai Pelayanan Informasi dan Pengembangan Usaha Pariwisata Dinas Pariwisata dan Kebudayaan Provinsi Jawa Tengah, pada saat ini sarana transportasi yang ada adalah kapal Muria dan kapal cepat Cantika (Jawa Pos, Minggu 17 Maret 2013). Saat ini Dinas Pariwisata dan Kebudayaan Jawa Tengah masih mengandalkan objek wisata air di Kepulauan Karimunjawa, contohnya objek penyelaman, pemancingan, dan snorkling. Terdapat 18 (delapan belas) titik wisata menyelam (diving) antara lain di Pulau Geleang, Pulau Sintok, Pulau Tengah, Pulau Mencawakan, Pulau Cemara Besar, Pulau Legan Moto, Pulau Tanjung Gelam, Pulau Katang, Pulau Kumbang, dan Pulau Menjangan Kecil. Selain itu terdapat pula objek wisata darat seperti hiking dan tracking di daerah hutan mangrove.

Berdasarkan hasil wawancara dengan beberapa wisatawan bahwa waktu tunggu untuk melakukan kunjungan wisata menuju Karimunjawa cukup padat dan lama, hal ini dikarena sarana transportasi kapal laut untuk menuju ke lokasi jumlahnya tidak memadai, sehingga diperlukan sarana transportasi tambahan untuk memenuhi kebutuhan masyarakat dan wisatawan baik domestik maupun mancanegara.

Sebuah perusahaan dari Singapura bernama Widgetwor telah mengembangkan alat transportasi berjenis amfibi. Alat transportasi ini diharapkan mampu menjawab tantangan konektivitas di negara-negara kepulauan seperti Indonesia, Polynesi, Filipina, Karibia, dan wilayah-wilayah kepulauan lainnya.

Di luar negeri, kapal amfibi seperti di Amerika Serikat, Inggris, Australia, dan Singapura tersedia secara komersial untuk tujuan rekreasi (Kim, Park, Hwang, Park, \& Camliyurt, 2021). Sistem transportasi tersebut adalah konsep kapal laut bersayap yang mampu mengudara dari atas air dengan kecepatan 196 km/jam. Kapal terbang yang diberi nama Airfish 8 (wigs) itu dapat mengakomodasi 8 (delapan) orang. Sekarang kendaraan ini sedang melalui proses design dan direncanakan untuk dikembangkan untuk dapat memuat lima puluh penumpang. Airfish 8 (AF8) adalah kapal dengan efek wingin-ground dengan desain operasional untuk dua orang crew, yang lebih besar kecenderungan fungsinya sebagai kapal ketimbang sebagai pesawat. Meski memang dari segi desain wigs lebih menyerupai pesawat. Menurut Daily Mail (Collins, 2018), AirFish 8 (AF8) dapat mengangkut antara enam hingga delapan orang.

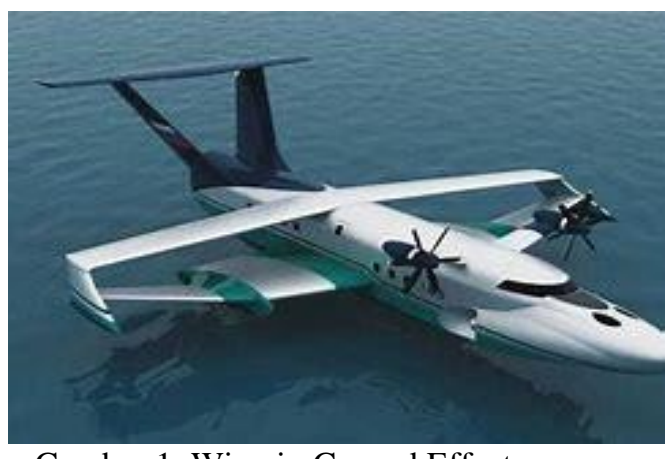

Gambar 1. Wing in Ground Effect Sumber:

www.pinterest.com/pin/374643262730281628/ 
Prototipe yang dibuat di Jerman ini memiliki panjang tujuh belas meter dengan lebar lima belas meter. Prototipe ini tiga kali lebih cepat dibanding kapal feri. Kendaraan ini memerlukan landasan dengan panjang minimal 500m.

Kapal ini ditenagai mesin V8 500bhp berkapasitas 7 liter dengan bahan bakar 95 oktan yang menyebabkan kendaraan ini lebih hemat dalam hal biaya konsumsi bahan bakar jika dibandingkan dengan avtur. Kapal ini meluncur di atas air dengan dorongan dari aerodynamic lift yang menyebabkan efek antar kapal dengan air sekitar setengah hingga 6 meter di atas permukaan air. Wigs juga mampu beroperasi di atas air dengan kecepatan 100 knots. Sebagai kendaraan waterborne, wigs tidak memerlukan runway untuk mengudara atau mendarat. Fitur tersebut meminimalisir biaya operasional jika kelak dikomersilkan baik oleh pemerintah maupun swasta.

Wigs hanya memerlukan stasiun bersandar yang sederhana dan murah. Stasiun bersandar Wigs dapat berupa dermaga kayu ataupun ponton plastik. Wigs yang hanya memiliki lambung kapal kecil memungkinkan untuk membangun stasiun bersandar di perairan dangkar dekat dengan garis pantai, kelebihan Wigs adalah sistem ini mampu menjangkau tempat yang tidak dapat dijangkau kapal feri atau pesawat terbang. Wigs juga didesain dengan sistem keamanan tinggi yang meminimalisir terjadinya engine hardware failure (kegagalan mesin), daya terbang Wigs yang masuk kategori lower flight altitude and above sea-water, akan meminimalisir mabuk laut secara signifikan. Singkatnya, sistem transportasi ini memiliki banyak keunggulan seperti sangat aman, cepat, dan nyaman sekaligus mode transportasi yang murah.

Berdasarkan hasil pengamatan peneliti bahwa sarana transportasi yang dibutuhkan untuk memajukan pariwisata di Jepara dan Karimunjawa saat ini dan yang akan datang adalah kapal motor cepat dengan desain kapal barang penumpang/cargo-passanger vessel, disamping itu untuk mengangkat pamor di dunia wisata di era digital 4.0 di mata dunia dan juga untuk menambah PAD sudah saatnya menggunakan kapal yang bisa terbang rendah atau lebih dikenal dengan Weign In Ground (WIG). Dari permasalahan tersebut di atas maka peneliti melakukan penelitian dengan tujuan untuk mendeskripsikan peningkatan Pendapatan Asli Daerah (PAD) atas obyek wisata dengan penambahan armada kapal penumpang cepat berbasis wing in grounds effect craft (WIG) pada obyek wisata Karimunjawa, Jepara.

Peraturan mengenai kepariwisataan yang tertuang dalam UndangUndang Nomor 10 Tahun 2009 menjelaskan definisi kepariwisataan sebagai semua aktivitas yang berhubungan dengan pariwisata dan bersifat multi dimensi serta multidisiplin yang muncul sebagai wujud kebutuhan setiap orang dan negara serta interaksi antara wisatawan dan masyarakat setempat, sesama wisatawan, pemerintah, pemerintah daerah, dan pengusaha. Di Kepulauan Karimunjawa, wilayah yang dikembangkan belum sampai 50 (lima puluh) persen, khususnya yang berhubungan dengan aktivitas ekonomi yang berhubungan dengan proses keluar masuk atau pergerakan wisatawan asing di dalam kota. Ida Ayu Suryasih, 2020 dalam bukunya Pemikiran Kepariwisataan Masa Jeda Pariwisata Untuk Bangkit menyebutkan: "Pariwisata adalah suatu perjalanan yang dilakukan untuk sementara waktu, yang diselenggarakan dari suatu tempat ke tempat lain dengan maksud bukan untuk berusaha (business) atau mencari nafkah di tempat yang dikunjungi, tetapi semata-mata untuk menikmati perjalanan tersebut guna bertamasya dan rekreasi atau untuk memenuhi keinginan yang beraneka ragam". Selain itu, pariwisata tidak hanya faktor pendorong bagi ekonomi lokal dan regional tetapi juga katalis 
untuk semua bidang kegiatan yang berhubungan langsung dan tidak langsung dengan perusahaan wisata (Bandoi, Jianu, Enescu, Axinte, Tudor, \& Firoiu, 2020).

Dari pengertian wisata tersebut di atas dapat disimpulkan bahwa yang dimaksud wisata adalah sebuah pelawatan dengan waktu yang tertentu dan terbatas yang dimaksudkan untuk berekreasi dan bertamasya yang dilakukan secara sadar dan sukarela.

Objek wisata atau dengan istilah "tourist attraction" yaitu segala sesuatu yang menjadi daya tarik bagi orang untuk mengunjungi suatu daerah tertentu (Sufika, 2004: 3). Bila dipelajari dengan teliti definisi tersebut, disimpulkan ada tiga kebutuhan utama yang harus dipenuhi oleh suatu daerah untuk menjadi tujuan wisata, yaitu (1) memiliki atraksi atau objek menarik, (2) mudah dicapai dengan alat-alat transportasi, dan (3) menyediakan tempat untuk tinggal sementara.

Pengembangan objek wisata merupakan salah satu usaha yang dilakukan secara sadar dan berencana dengan memperbaiki dan memperbanyak objek wisata sebagai suatu daerah tujuan wisata baik secara lokal, regional atau ruang lingkup nasional yang erat kaitannya dengan pembangunan perekonomian daerah atau negara tersebut. Pengembangan kepariwisataan pada suatu daerah tujuan wisata selalu akan diperhitungkan dengan keuntungan dan manfaat bagi rakyat banyak. Bila pada suatu daerah tujuan wisata industri pariwisata berkembang dengan baik dengan sendirinya akan memberikan dampak positif bagi daerah itu, karena itu dapat menciptakan lapangan kerja yang cukup luas bagi penduduk setempat. Secara langsung dengan di bangunnya sarana dan prasarana pariwisata di daerah itu maka tenaga kerja akan banyak disedot oleh proyek-proyek, pembuatan jalanjalan ke objek-objek pariwisata, jembatan, pembangkit tenaga listrik, persediaan air bersih, pembangunan tempat-tempat rekreasi, objek wisata, angkutan wisata, terminal dan lapangan udara, perhotelan, restoran, biro perjalanan, butik, pusat perbelanjaan, souvenirshop, sanggar-sanggar kesenian dan tempat hiburan lainnya. Dan bahkan bukan itu saja, dengan banyaknya permintaan baru akan hasil-hasil pertanian, peternakan, perkebunan, industri perabot rumah tangga, kerajinan kecil dan pertenunan serta pendidikan untuk melayani wisatawan yang datang dan selalu akan diperhitungkan dengan keuntungan dan manfaat bagi rakyat banyak, bahkan dampak uang beredar yang dibelanjakan wisatawan pada suatu daerah tujuan wisata sangat besar pengaruhnya bagi daerah tujuan wisata atau negara yang mengembangkan pariwisata sebagai suatu industri. Tidak hanya akan dapat meningkatkan penerimaan devisa negara, pendapatan nasional, penerimaan pajak dan Pendapatan Asli Daerah (PAD) tetapi sekaligus akan memperkuat posisi neraca pembayaran negara.

Dengan adanya kegiatan pariwisata akan timbul hasrat dan keinginan untuk memelihara semua asset wisata yang dimaksud. Dengan kata lain industri pariwisata dapat dikatakan sebagai industri tanpa cerobong asap yang bebas dari polusi dan pencemaran lainnya. Walaupun kegiatan kepariwisataan banyak dipengaruhi oleh kemajuan teknologi, transportasi dan komunikasi, tetapi tempat-tempat yang menjadi pemusatan wisatawan itu selalu menghendaki suasana yang nyaman, bersih, dan aman dan memiliki lingkungan terpelihara sehingga tercipta suasana harmonis dan menyenangkan bagi semua pengunjung.

Di dalam kepariwisataan, pengembangan produk baru perlu menjadi pemikiran ahli-ahli pariwisata, khususnya para pengelola yang langsung menangani sektor kepariwisataan tersebut. Seperti kita ketahui, produk industri pariwisata itu sangat bervariasi dan bermacam-macam sesuai dengan keinginan dan kemampuan wisatawan 
itu sendiri.

Berhubung produk dalam kepariwisataan pada umumnya berupa suatu packages, maka pengembangan produk itu hendaknya mencakup semua unsur yang melengkapi suatu packages tours tersebut. Paket wisata telah diakui sebagai alat yang efektif untuk menarik wisatawan (Rong, Tu, Duarte, \& Ratti, 2020). Jadi pengembangan produk baru itu dapat meliputi perubahan perbaikan pelayanan (services) semenjak seseorang wisatawan meninggalkan tempat kediamannya sampai ke tempat/objek yang dituju sampai kembali ke tempat asalnya.

Fasilitas penunjang pariwisata yaitu fasilitas di luar objek wisata yang menunjang industri pariwisata dapat berupa: travel agents, tourist transportations, hotel dan penginapan, bar dan restoran, dan tour operator (guide), sehingga akan semakin terbuka luas hubungan antara masyarakat dengan wisatawan sekaligus dapat memberikan dampak positif maupun negatif, meliputi sarana peralatan dan perlengkapan yang secara khusus langsung dipergunakan dan menunjang proses pekerjaan, prasarana kantor dan sarana objek wisata yang ada di objek wisata, meliputi gedung perkantoran, rumah sakit, ruang pertemuan, kolam renang, taman bermain, kebun, gardu pandang, bumi perkemahan, pentas seni, dan souvenir. Adapun yang dimaksud dengan prasarana objek wisata adalah fasilitas yang secara tidak langsung menunjang pariwisata, seperti loket, MCK, halaman tempat parkir, dermaga, kebun, taman, jalur jalan santai, dan keamanan, tak kalah pentingnya harus mampu menerapkan teknik pemasaran yang profesional dalam perencanaan, pelaksanaan, dan melakukan pemasaran terhadap program promosinya. Program promosi yang baik akan mendorong konsumen untuk membeli produk yang telah dihasilkan perusahaan.

$$
\text { Pada umumnya industri }
$$

pariwisata pun menerapkan program promosi wisata dengan menggunakan system promotion mix, pengertian promotion mix yaitu kombinasi strategi yang paling baik dari variabel-variabel periklanan, personal selling dan alat promosi yang lain yang kesemuanya direncanakan untuk mencapai tujuan program penjualan". Perlu diperhitungkan bagi pelaku wisata akan jumlah kunjungan wisatawan lokal, domestik dan mancanegara. (1) Jumlah wisatawan lokal adalah anggota masyarakat dalam kabupaten/ kota yang melakukan kegiatan berwisata pada obyek-obyek wisata dalam daerahnya (titing kartika, 2020), yang dilihat dari aspek jumlah arus kunjungan wisata pada obyek wisata alam dan jumlah arus kunjungan wisata pada obyek wisata budaya. (2) Jumlah wisatawan domestik adalah anggota masyarakat daerahdaerah lain dalam negeri yang melakukan kunjungan wisata pada obyek-obyek wisata di kabupaten/kota, yang dilihat dari aspek jumlah arus kunjungan wisata pada obyek wisata alam dan jumlah arus kunjungan wisata pada obyek wisata budaya. (3) Jumlah wisatawan mancanegara adalah warga negara asing yang melakukan kunjungan wisata pada obyek-obyek wisata di kabupaten/kota yang dilihat dari aspek jumlah arus kunjungan wisata pada obyek wisata alam dan jumlah arus kunjungan wisata pada obyek wisata budaya.

Menurut Mamesah (dalam Dewi, 2002: 7), keuangan daerah adalah semua hak dan kewajiban yang dapat dinilai dengan uang, demikian pula segala sesuatu baik berupa uang maupun barang yang dapat dijadikan kekayaan daerah sepanjang belum dimiliki/dikuasai oleh negara atau daerah yang lebih tinggi serta pihak-pihak lain sesuai dengan peraturan perundang-undangan yang berlaku. Sejalan dengan pemberian urusan kepada daerah termasuk sumber keuangannya, maka dalam bunyi pasal 79 Undang-Undang Nomor 32 Tahun 2004 disebutkan bahwa pendapatan asli daerah terdiri dari: (1) Hasil pajak daerah, (2) Hasil retribusi daerah, (3) 
Hasil perusahaan milik daerah, dan hasil pengelolaan milik daerah yang dipisahkan dan, (4) Lain-lain pendapatan asli daerah yang sah.

Adapun dalam research gap yang dapat dilihat: (1) Menurut Fatah Hidayat dalam tesisnya dengan judul Program Promosi Pariwisata Dalam Meningkatkan Pendapatan Asli Daerah, Pendapatan Masyarakat, Perluasan Usaha dan Kesempatan Kerja di Propinsi Bengkulu, mengatakan "Perencanaan dan pelaksanaan program promosi pariwisata pada dasarnya mempunyai dampak terhadap Pendapatan Asli Daerah (PAD), perluasan usaha, penyerapan tenaga kerja dan pendapatan masyarakat melalui arus kunjungan wisatawan. Hal ini disebabkan keterkaitan antara pelaksanaan program promosi pariwisata dengan usaha untuk meningkatkan arus kunjungan wisatawan. Dengan meningkatnya arus kunjungan wisatawan maka akan berdampak akan penerimaan PAD berupa pajak hotel, restoran serta retribusi masuk pada kesempatan berusaha dan pendapatan masyarakat terutama para pengusaha dan pekerja di bidang kepariwisataan seperti: hotel, travel, toko cinderamata, PKL dan pramu wisata". (2) Murjani dalam tesisnya dengan judul Perkembangan Industri Pariwisata Terhadap Perluasan Kesempatan Kerja Serta Pendapatan Asli Daerah di Propinsi Kalimantan Timur mengatakan "Hasil analisis data untuk melihat dampak industri pariwisata terhadap penyerapan tenaga kerja menunjukkan bahwa secara serempak atau bersama-sama variable jumlah hotel, jumlah wisatawan baik mancanegara maupun nusantara, jumlah restoran, dan rumah makan, jumlah biro perjalanan, serta jumlah toko souvenir di Kalimantan Timur dapat menyerap tenaga kerja. Selama beberapa tahun terakhir, tingkat kunjungan wisatawan ke Jepara dan Pulau Karimunjawa pengunjung selalu meningkat dari bulan ke bulan dan kedatangan pengunjung mencapai puncaknya pada saat akhir tahun dengan jumlah pengunjung ratarata 2,6 juta orang. Dengan meningkatnya jumlah kunjungan wisatawan diasumsikan juga meningkatkan pendapatan objek wisata. Untuk itu diteliti pula pengaruh fasilitas penunjang, sarana dan prasarana pariwisata, dan biaya promosi pariwisata terhadap pendapatan objek wisata. Selanjutnya diteliti pengaruh jumlah kunjungan wisatawan dan pendapatan objek wisata terhadap Pendapatan Asli Daerah.

Keberadaan Dinas Pariwisata dan Kebudayaan di Kabupaten Jepara dibentuk dengan Peraturan Pemerintah Daerah (PERDA) Nomor 17 Tahun 2010 tentang Organisasi dan Tata Kerja Dinas Daerah Kabupaten Jepara. PERDA ini menegaskan bahwa dalam rangka mengoptimalkan pelayanan kepada masyarakat serta pemberdayaan perangkat daerah untuk dapat lebih efektif dan efisien dalam melaksanakan urusan, maka dipandang perlu untuk melakukan penyelarasan dan penataan kembali organisasi perangkat daerah yang ada di Kabupaten Jepara.

Di dalam melaksanakan tugas pokok tersebut, dinas pariwisata dan kebudayaan Kabupaten Jepara menyelenggaraan usaha pariwisata dengan memperhatikan keanekaragaman, keunikan, dan kekhasan budaya dan alam, serta kebutuhan manusia untuk berwisata. Penyelenggaraan usaha pariwisata ini berfungsi memenuhi kebutuhan jasmani, rohani dan intelektual setiap wisatawan. Berdasarkan Pasal 5 PERDA Kabupaten Jepara Nomor 09 tentang Penyelenggaraan Usaha Pariwisata, Penyelenggaraan Usaha Pariwisata bertujuan untuk meningkatkan pertumbuhan ekonomi, meningkatkan kesejahteraan rakyat, menghapus kemiskinan, mengatasi pengangguran, melestarikan alam, lingkungan, dan sumber daya, memajukan kebudayaan, mengangkat kekhasan dan citra daerah, memupuk rasa cinta tanah air, memperkukuh jati diri dan kesatuan 
nasional, dan mempererat persahabatan antar daerah.

\section{METODE PENELITIAN}

Metode yang digunakan dalam penelitian ini adalah kuantitatif dengan jenis assosiatif. Pada penelitian ini, tidak melakukan treatment, melainkan meneliti masalah atau peristiwa yang telah terjadi dan tidak melakukan kontrol terhadap variabel penelitian, melainkan melihat variabel sebagaimana adanya sehingga penelitian ini menggunakan pendekatan ex post facto. Bahwa metode ex post facto maksudnya adalah penelitian empiris sistematis ini tanpa melakukan perlakuan-perlakuan maupun manipulasi terhadap variabel penelitian tetapi hanya mengumpulkan fakta-fakta berdasarkan pengukuran terhadap gejala yang terjadi pada diri responden sebelumnya (Gempur Santoso, 2007). Penelitian ini dilaksanakan di obyek wisata Kabupaten Jepara dan Karimunjawa. Penelitian dilaksanakan pada minggu terakhir Juni sampai dengan minggu pertama Oktober 2020.

Untuk lebih jelasnya kerangka pemikiran tersebut divisualisasikan dalam Gambar 2 berikut.

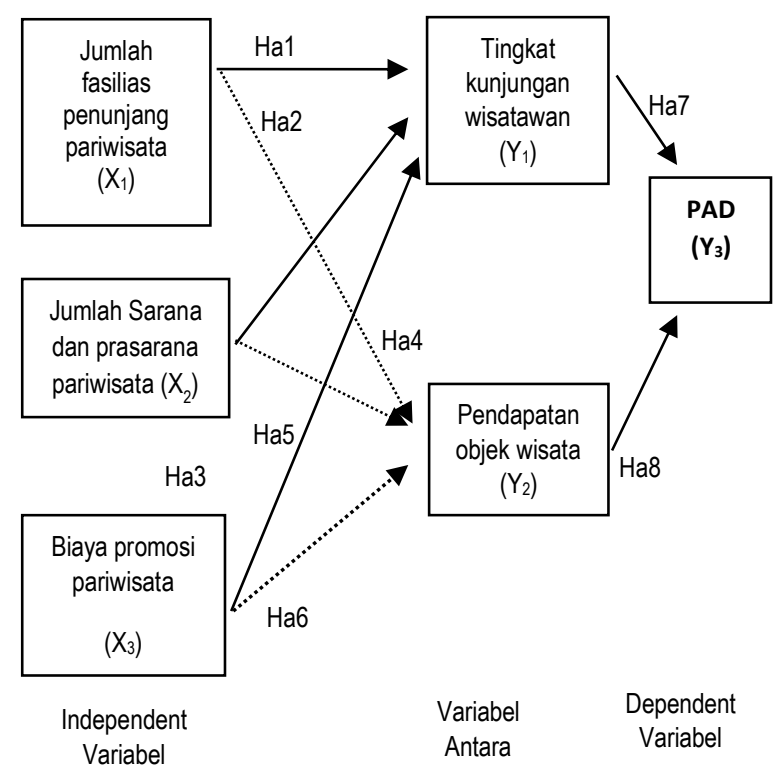

Gambar 2. Kerangka Berpikir Penelitian

Dalam penelitian ini kami menggunakan data fasilitas penunjang pariwisata dengan jumlah 247, sarana dan prasarana sejumlah 594, data biaya promosi pariwisata sejumlah Rp436.250.000,- pada tahun 2013 dan data tersebut kita gunakan sebagai Independent Variable dan data kunjungan wisatawan sejumlah 1.097.472, pendapatan obyek wisata sejumlah Rp28.077.000,- digunakan sebagai variable antara. Teknik sampling yang digunakan penelitian ini adalah purposive sampling, yaitu sampel diambil didasarkan atas tujuan tertentu. Analisis data dilakukan secara kuantitatif dan kualitatif.

\section{HASIL DAN PEMBAHASAN}

Dalam penelitian kami menggunakan uji normalitas data secara statistik dengan menggunakan Kolmogorov-Smirnov dengan Lilliefors Significance Correction yang dihitung dengan program SPSS 22. Pengambilan keputusan berdasarkan nilai probabilitas. Dari data yang diperoleh terdapat enam data yang patut diperhitungkan sebagai pusat pengaruh kepariwisataan yang ada di Jepara yaitu: data jumlah fasilitas penunjang pariwisata obyek wisata $\left(\mathrm{X}_{1}\right)$, data jumlah sarana dan prasarana pariwisata $\left(\mathrm{X}_{2}\right)$, data biaya promosi pariwisata $\left(\mathrm{X}_{3}\right)$, data tingkat kunjungan wisatawan $\left(\mathrm{Y}_{1}\right)$, data Pendapatan Obyek Wisata $\left(\mathrm{Y}_{2}\right)$ dan data Pendapatan Asli Daerah $\left(\mathrm{Y}_{3}\right)$.

Dari hasil analisa yang peneliti lakukan nampak sekali adanya beberapa perbedaan dari tahun 2008-2013 dengan 2015-2019 akibat pengaruh dari jumlah kedatangan pengunjung baik Wisman maupun Wisnus.

1. Pengaruh jumlah fasilitas penunjang pariwisata $\left(\mathrm{X}_{1}\right)$ terhadap tingkat kunjungan wisatawan $\left(\mathrm{Y}_{1}\right)$.

Berdasarkan analisis data terbukti bahwa ada pengaruh yang signifikan dukungan jumlah fasilitas penunjang pariwisata terhadap tingkat kunjungan wisatawan di Kabupaten Jepara.

2. Pengaruh jumlah sarana dan prasarana pariwisata $\left(\mathrm{X}_{2}\right)$ terhadap 
tingkat kunjungan wisatawan $\left(\mathrm{Y}_{1}\right)$

Berdasarkan analisis data terbukti bahwa ada pengaruh yang signifikan jumlah sarana dan prasarana pariwisata terhadap tingkat kunjungan wisatawan di Kabupaten Jepara. Beberapa jumlah sarana dan prasarana pariwisata kabupaten Jepara dalam penelitian ini meliputi: (1) jumlah gedung perkantoran, (2) jumlah ruang pertemuan, (3) jumlah kolam renang, (4) jumlah taman bermain, (5) jumlah kebun dan taman, (6) jumlah gardu pandang, (7) jumlah bumi perkemahan (camping ground), (8) jumlah pertunjukan pentas seni, dan (9) jumlah toko penjualan souvenir. Adapun prasarana pariwisata berupa: (1) jumlah loket, (2) jumlah MCK, (3) jumlah tempat parkir, (4) jumlah jalur jalan santai, (5) jumlah personil keamanan, dan (6) jumlah pemandu wisata (guide). Semua ini faktor tersebut memberikan pengaruh terhadap tingkat kunjungan wisatawan.

3. Pengaruh biaya promosi pariwisata $\left(\mathrm{X}_{3}\right)$ terhadap tingkat kunjungan wisatawan $\left(\mathrm{Y}_{1}\right)$.

Terbukti pula bahwa ada pengaruh yang signifikan dukungan promosi pariwisata terhadap tingkat kunjungan wisatawan di Kabupaten Jepara. Biaya promosi pariwisata Kabupaten Jepara dalam penelitian ini adalah jumlah anggaran yang digunakan untuk membiayai pelaksanaan kegiatan yang berkaitan dengan usaha mendekatkan segala sesuatu mengenai informasi dunia kepariwisataan di Kabupaten Jepara dalam rangka menggugah para wisatawan untuk berkunjung pada obyek-obyek wisatanya, dilihat dari aspek: Jumlah uang dikeluarkan Pemda Kabupaten Jepara setiap tahun untuk membiayai kegiatan promosi pariwisata dan berbagai jenis pembiayaan dalam pelaksanaan promosi pariwisata.

4. Pengaruh jumlah fasilitas penunjang pariwisata $\left(\mathrm{X}_{1}\right)$ terhadap pendapatan objek wisata $\left(\mathrm{Y}_{2}\right)$

Berdasarkan analisis data terbukti bahwa tidak ada pengaruh yang signifikan jumlah fasilitas penunjang pariwisata terhadap pendapatan obyek wisata di Kabupaten Jepara. Hal ini disebabkan jumlah fasilitas penunjang merupakan faktor eksternal dari obyek wisata yang tidak ada hubungannya dengan pendapatan obyek wisata. Fasilitas penunjang pariwisata yaitu berupa: (1) jumlah travel agents, (2) jumlah tourist transportations, (3) Jumlah transportasi berupa kapal penumpang (4) jumlah hotel dan penginapan, (5) jumlah rumah makan dan restoran, dan (6) jumlah tour operator. Adapun pendapatan obyek wisata berasal dari: harga tiket/karcis masuk pada obyekobyek wisata (alam dan budaya) dan tempat hiburan di Kabupaten Jepara serta harga tiket/karcis pada masingmasing stand hiburan di dalam obyekobyek wisata (alam dan budaya) dan tempat hiburan di kabupaten Jepara. Kedua variabel ini tidak saling berhubungan secara langsung.

5. Pengaruh jumlah sarana dan prasarana pariwisata $\left(\mathrm{X}_{2}\right)$ terhadap pendapatan objek wisata $\left(\mathrm{Y}_{2}\right)$.

Berdasarkan analisis data terbukti bahwa tidak ada pengaruh yang signifikan jumlah sarana dan prasarana pariwisata terhadap pendapatan obyek wisata di Kabupaten Jepara. Hal ini disebabkan jumlah sarana dan prasarana memang bisa meningkatkan tingkat kunjungan wisatawan, namun tidak semua wisatawan memanfaatkan berbagai stand hiburan yang ada di dalam obyek wisata. Pemanfaatan jumlah sarana dan prasarana dalam obyek wisata bergantung pada minat wisatawan tersebut dan kemampuan financial yang dimiliki wisatawan.

6. Pengaruh biaya promosi pariwisata $\left(\mathrm{X}_{3}\right)$ terhadap pendapatan objek wisata $\left(\mathrm{Y}_{2}\right)$.

Berdasarkan analisis data terbukti bahwa tidak ada pengaruh 
yang signifikan biaya promosi pariwisata terhadap pendapatan obyek wisata di Kabupaten Jepara. Hal ini disebabkan biaya promosi pariwisata memang bisa meningkatkan tingkat kunjungan wisatawan, namun tidak semua wisatawan memanfaatkan berbagai stand hiburan yang ada di dalam obyek wisata. Pemanfaatan jumlah sarana dan prasarana dalam obyek wisata bergantung pada minat wisatawan tersebut dan kemampuan finansial yang dimiliki wisatawan. Pendapatan obyek wisata bergantung pada minat wisatawan tersebut dan kemampuan financial yang dimiliki wisatawan untuk membeli tiket berbagai stand yang ada dalam obyek wisata. Karena pendapatan obyek wisata berasal dari: harga tiket/karcis masuk pada obyek-obyek wisata (alam dan budaya) dan harga tiket /karcis pada masing-masing stand hiburan di dalam obyek-obyek wisata (alam dan budaya).

7. Pengaruh tingkat kunjungan wisatawan $\left(\mathrm{Y}_{1}\right)$ terhadap Pendapatan asli daerah $\left(\mathrm{Y}_{3}\right)$

Adapun tingkat kunjungan wisatawan tidak berpengaruh signifikan terhadap Pendapatan Asli Daerah Kabupaten Jepara. Tingkat kunjungan wisatawan dalam obyek wisata tidak selalu meningkatkan pendapatan objek wisata, karena bergantung pada minat wisatawan tersebut dan kemampuan finansial yang dimiliki wisatawan untuk membeli tiket berbagai stand yang ada dalam obyek wisata. Demikian pula, pendapatan asli daerah tidak dipengaruhi oleh tingkat kunjungan wisatawan. Hal ini dapat dipahami, karena secara teori tingkat kunjungan wisatawan tidak ada hubungan langsung dengan PAD. Dalam pasal 79 Undang-Undang Nomor 32 Tahun 2004 dicantumkan sumber-sumber pendapatan daerah terdiri atas: (a). Pendapatan asli daerah yaitu: hasil pajak daerah, hasil retribusi daerah, hasil perusahaan milik daerah, hasil pengelolaan kekayaan daerah dan lain-lain pendapatan daerah yang sah, (b) Dana Perimbangan, (c) Pinjaman daerah, dan (d) lain-lain pendapatan daerah yang sah.

8. Pengaruh pendapatan objek wisata $\left(\mathrm{Y}_{2}\right)$ terhadap pendapatan asli daerah $\left(\mathrm{Y}_{3}\right)$.

Adapun pendapatan obyek wisata berpengaruh positif dan signifikan terhadap Pendapatan Asli Daerah Kabupaten Jepara. Sebagaimana diketahui bahwa pendapatan obyek wisata adalah sumber-sumber penerimaan uang yang berasal dari: (a) besarnya harga tiket /karcis masuk pada obyek-obyek wisata (alam dan budaya) dan tempat hiburan di Kabupaten Jepara dan (b) besarnya harga tiket/karcis pada masing-masing stand hiburan di dalam obyek-obyek wisata (alam dan budaya) dan tempat hiburan di Kabupaten Jepara. Pada praktiknya, tidak semua wisatawan memanfaatkan berbagai stand hiburan yang ada di dalam obyek wisata. Pemanfaatan jumlah sarana dan prasarana dalam obyek wisata bergantung pada minat wisatawan tersebut dan kemampuan finansial yang dimiliki wisatawan. Hal ini dapat dipahami, karena obyek wisata Kabupaten Jepara adalah yang cukup besar di Jawa Tengah. Pendapatan Asli Daerah (PAD) dari sektor pariwisata berasal dari pajak dan retribusi, yaitu pajak hotel, motel, dan restoran atau rumah makan di Kabupaten Jepara dan retribusi yang berasal dari pungutan karcis masuk pada obyek-obyek wisata (alam dan budaya) dan tempat hiburan.

\section{SIMPULAN}

Dalam penelitian tentang peningkatan pendapatan asli daerah (PAD) atas obyek wisata JeparaKarimunjawa dapat disimpulkan bahwa jumlah fasilitas penunjang pariwisata, jumlah sarana dan prasarana pariwisata, 
dan biaya promosi pariwisata mempunyai pengaruh yang signifikan terhadap tingkat kunjungan wisatawan. Hal ini tampak dari data hasil penelitian mengenai variabel jumlah fasilitas penunjang pariwisata yang berpengaruh signifikan terhadap tingkat kunjungan wisatawan. Jumlah sarana dan prasarana berpengaruh signifikan terhadap tingkat kunjungan wisatawan, serta biaya promosi pariwisata terhadap tingkat kunjungan wisatawan. Sehingga biaya promosi pariwisata Kabupaten Jepara dalam penelitian ini sangat diperlukan dan juga anggaran yang digunakan untuk membiayai pelaksanaan kegiatan yang berkaitan dengan usaha mendekatkan segala sesuatu mengenai informasi dunia kepariwisataan di Kabupaten Jepara dalam rangka menggugah para wisatawan untuk berkunjung pada obyek-obyek wisatanya.

Kemudian tidak ada pengaruh yang signifikan antara jumlah fasilitas penunjang pariwisata, jumlah sarana dan prasarana pariwisata serta biaya promosi pariwisata terhadap pendapatan obyek wisata. Hal ini disebabkan jumlah sarana dan prasarana memang bisa meningkatkan tingkat kunjungan wisatawan, namun tidak semua wisatawan memanfaatkan berbagai stand hiburan yang ada di dalam obyek wisata. Begitu juga dengan biaya promosi pariwisata memang bisa meningkatkan tingkat kunjungan wisatawan, namun tidak semua wisatawan memanfaatkan berbagai stand hiburan yang ada di dalam obyek wisata. Pemanfaatan jumlah sarana dan prasarana dalam obyek wisata bergantung pada minat wisatawan tersebut dan kemampuan finansial yang dimiliki wisatawan. Kemudian ada pengaruh signifikan antara pendapatan obyek wisata terhadap pendapatan asli daerah Sebagaimana diketahui bahwa pendapatan obyek wisata adalah sumbersumber penerimaan uang yang berasal dari: (a) besarnya harga tiket/karcis masuk pada obyek-obyek wisata (alam dan budaya) dan tempat hiburan di
Kabupaten Jepara dan (b) besarnya harga tiket/karcis pada masing-masing stand hiburan di dalam obyek-obyek wisata (alam dan budaya) dan tempat hiburan di Kabupaten Jepara.

Berkaitan dengan hasil dan kesimpulan penelitian ini, maka peneliti merekomendasikan beberapa saran. Bagi Kepala Dinas Pariwisata dan Kebudayaan Kabupaten Jepara disarankan menambah beberapa fasilitas penunjang pariwisata, memperbaiki sarana dan prasarana serta melakukan promosi yang lebih maksimal agar meningkatkan jumlah wisatawan yang berkunjung ke Karimunjawa-Jepara, melalui berbagai pengembangan wisata. Salah satunya dengan pengadaan WIG sebagai sarana transportasi wisata laut sehingga dapat meningkatkan pendapatan obyek wisata secara maksimal.

Harus ada koordinasi antara Dinas Pariwisata dan Kebudayaan Kabupaten Jepara dengan Kementerian Perhubungan agar terjalin koordinasi yang baik. Hal ini terkait dengan pengadaan sarana transportasi. Untuk meningkatkan pendapatan objek wisata perlu ditingkatkan promosi pada setiap stand di objek wisata sehingga meningkatkan pendapatan asli daerah.

\section{DAFTAR PUSTAKA}

Bandoi, A., Jianu, E., Enescu, M., Axinte, G., Tudor, S., \& Firoiu, D. (2020). The Relationship between Development of Tourism, Quality of Life and Sustainable Performance in EU Countries. Sustainability, Vol. 12(4).

Collins, T. (2018, February 28). The incredible flying BOAT: Winged Airfish 8 vehicle can carry 8 passengers while soaring above water at 120mph. Retrieved September 28, 2021, from Mail Online:

https://www.dailymail.co.uk/scie ncetech/article-5444107/Airfish8-carry-8-passengers-water- 
$120 \mathrm{mph} . \mathrm{html}$

Dewi, Elita.( 2002). Identifikasi Sumber Pendapatan Asli Daerah Dalam Rangka Pelaksanaan Otonomi Daerah. USU.

Hidayat, Fatah.(2003). "Program promosi pariwisata dalam meningkatkan Pendapatan Asli Daerah, pendapatan masyarakat, perluasan usaha dan kesempatan kerja di Propinsi Bengkulu". Tesis. UGM

Gempur Santoso. (2007). Metodologi Penelitian Kuantitatif dan Kualitatif. Rineka Cipta.

Howlett, M., \& Cashore, B. (2014). Conceptualizing Public Policy. In Engeli I., Allison C.R. (eds), Comparative Methods Series. Palgrave Macmillan.

Suryasih, Ida Ayu. (2020). Pemikiran Kepariwisataan Masa Jeda Pariwisata untuk Bangkit. Uwais Inspirasi Indonesia

Kim, N.-E., Park, Y.-S., Hwang, S.-A., Park, M.-J., \& Camliyurt, G. (2021). A Study On The Preparation of Standards for The Safety of Domestic Amphibious Ships. Journal of International Maritime Safety, Environmental Affairs, and Shipping, 5:1, 12-21.

Lembaran Negara. (2009). UndangUndang Kepariwisataan "Undang-Undang

Kepariwisataan Nomor 10 Tahun 2009".

Lembaran Negara. UU Nomor 32 Tahun 2004 tentang Pemerintah Daerah.

Lembaran Negara. UU Nomor 33 Tahun 2004 dan tentang Perimbangan Keuangan antara Pemerintahan Pusat dan Pemerintah Daerah.

Lembaran Negara. Undang-Undang Republik Indonesia Nomor 10 tahun 2009 tentang Kepariwisataan.

Miceikiene, A., Skaurone, L., \& Krikstolaitis, R. (2021). Assessment of the Financial
Autonomy of Rural

Municipalities. Economics, Vol. $9(3)$.

Murjani. (1997). Perkembangan Industri Pariwisata Terhadap Perluasan Kesempatan Kerja serta Pendapatan Asli Daerah di Provinsi Kalimantan Timur". Tesis. UGM.

Peraturan Pemerintah Daerah (PERDA) Nomor 17 Tahun 2010 tentang "Organisasi dan Tata Kerja Dinas Daerah Kabupaten Jepara".

Rong, H. H., Tu, W., Duarte, F., \& Ratti, C. (2020). Employing waterborne autonomous vehicles for museum visits: a case study in Amsterdam. European Transport Research Review volume 12(63).

Satola, Lukasz, Standar, A., \& Kozera, A. (2019). Financial Autonomy of Local Government Units: Evidence from Polish Rural Municipalities. Lex LocalisJournal of Local SelfGovernment 17, 321-42.

Tanjung, A. H., Salam, S., Rusdi, J. F., Ermawati, Y., Novianty, I., Hendaris, R. B., et al. (2021). Flypaper effect assessment methods in the expansion of regional autonomy. MethodsX, Vol. 8 (101387).

Kartika, Titing. (2020). Literasi Pariwisata: dari Lokal Hingga Global. Deepublish

Wen, J., \& Wu, M.-Y. (2020). How special is special interest tourism - and how special are special interest tourists? A perspective article in a Chinese context. Current Issues in Tourism, 23:16, 1968-1972.

Zolfani, S. H., Sedaghat, M., Maknoon, R., \& Zavadskas, E. K. (2015). Sustainable tourism: a comprehensive literature review on frameworks and applications. Economic Research-Ekonomska Istraživanja, 28:1, 1-30. 